\title{
Zoning and weighting in urban heat island vulnerability and risk mapping in Helsinki, Finland
}

\author{
Aleksi Räsänen ${ }^{1,2} \mathbb{D} \cdot$ Kimmo Heikkinen $^{1} \cdot$ Noora Piila $^{1} \cdot$ Sirkku Juhola $^{1}$
}

Received: 19 June 2018 / Accepted: 15 March 2019 / Published online: 11 April 2019

(C) The Author(s) 2019

\begin{abstract}
Climate change is likely to increase the risks related to heat waves in urban areas. We map spatial pattern of heat wave vulnerability and risk in the Helsinki metropolitan area in southern Finland. First, we assess differences that zoning, i.e., differences in spatial units of analysis, and weighting, i.e., weights given to indicators when constructing the index, cause in map production. Second, we evaluate how maps of consensus and certainty could pave the way for visualizing and assessing uncertainties in risk and vulnerability indices. For vulnerability, we use socioeconomic data using 5 different zoning options and 11 different weighting options. For risk, we add two extra layers to vulnerability maps: hazard map showing the spatial pattern of heat based on Landsat satellite images and exposure map showing the spatial pattern of population. We found that when different zoning options are used, the spatial pattern of vulnerability may differ dramatically. In risk maps, the differences between zoning options are smaller. Contrary to previous literature, differences in indicator weighting alter the final maps slightly. The consensus and certainty maps show their potential, e.g., in pointing out areas which may have both high risk/vulnerability and high certainty for risk/vulnerability. Finally, we discuss other possibilities in tackling the uncertainties in mapping and propose new avenues for research.
\end{abstract}

Keywords Climate risk $\cdot$ Heat risk $\cdot$ Modifiable areal unit problem $\cdot$ Urban $\cdot$ Urban heat island $\cdot$ Vulnerability

\section{Introduction}

Climate change is likely to increase the risks related to heat waves (IPCC 2014; Zhou et al. 2017). The urban heat island (UHI) effect, denoting that temperatures in urban areas are higher than in surrounding areas (Oke 1982), magnifies the negative impacts of heat (Klein Rosenthal et al. 2014). Vulnerability to heat has been of interest to many when considering how climate change will impact cities (Abrahamson

\section{Editor: Marc J. Metzger}

Electronic supplementary material The online version of this article (https://doi.org/10.1007/s10113-019-01491-x) contains supplementary material, which is available to authorized users.

Aleksi Räsänen

aleksi.rasanen@helsinki.fi

Kimmo Heikkinen

kimmo.heikk@gmail.com

Noora Piila

noora.piila@gmail.com

Sirkku Juhola

sirkku.juhola@helsinki.fi et al. 2009; Conti et al. 2005; El-Zein and Tonmoy 2015), given that it is likely to be the climate impact that will cause most fatalities (Luber and McGeehin 2008).

During the past decade, there has been a rise in UHI mappings (de Groot-Reichwein et al. 2018; Ho et al. 2015; Huang et al. 2011; Lissner et al. 2012; Tomlinson et al. 2011; Weber et al. 2015). These maps are typically vulnerability or risk maps based on indices (e.g., Cutter et al. 2003; Preston et al. 2011; Reckien 2018). Indices combine several different

1 Ecosystems and Environment Research Programme, Faculty of Biological and Environmental Sciences, and Helsinki Institute of Sustainability Science (HELSUS), University of Helsinki, P.O Box 65, FI-00014 Helsinki, Finland

2 Department of Geography, Norwegian University of Science and Technology, NO-7491 Trondheim, Norway 
indicators, which in the case of UHI include elements linked, e.g., to spatial patterns of temperature, city structure, population density, and socioeconomic characteristics of the population within the city (de Groot-Reichwein et al. 2018; Ho et al. 2015; Huang et al. 2011; Lissner et al. 2012; Tomlinson et al. 2011; Weber et al. 2015). The index approaches have been subject to criticism on many grounds. Most notably, Hinkel (2011) argued that indices are ill-fit for steering mitigation and adaptation policies and raising awareness, although they are widely used in these purposes. This is because vulnerability cannot be readily measured and generalized using simple indices.

There are multiple steps in the map-making process which have effects on the final maps, and acknowledgement and analysis of the uncertainties could help to develop more robust mapping approaches (Tate 2012). The amount of uncertainty and its sources can be analyzed with sensitivity and uncertainty analyses (Borgonovo and Plischke 2016; Ferretti et al. 2016; Saisana et al. 2005). Uncertainty analysis means evaluation of how uncertainty in input factors affects index values, and sensitivity analysis denotes how much each uncertainty source contributes to the output variance (Saisana et al. 2005). There are multiple different methods for conducting sensitivity analyses (Borgonovo and Plischke 2016). Within vulnerability and risk index studies, both simple methods, such as manual indicator removal (Mainali and Pricope 2017), and more complicated techniques, such as Monte Carlo simulation and variance-based global sensitivity analysis (Feizizadeh and Kienberger 2017), have been used. Furthermore, while some have assessed only one or a few uncertainty sources (Feizizadeh and Kienberger 2017; Mainali and Pricope 2017; Schmidtlein et al. 2008), others have analyzed the relative contribution of multiple sources (Tate 2012).

Usually, in index-based vulnerability and risk maps, data is spatially aggregated to administrative boundaries, as pointlevel socioeconomic data is not commonly available (Jeffery et al. 2014). The aggregation of spatial data leads to problems in data analysis. The most notable of these problems is the modifiable areal unit problem (MAUP, Ho et al. 2015; Mas et al. 2015; Perveen and James 2012). The inherent problem with the MAUP is that areas can be delineated in a multitude of ways, and results calculated from the differing areas vary (Fotheringham and Wong 1991; Openshaw and Baxter 1977; Páez and Scott 2005). MAUP becomes evident when the original higher-resolution dataset is either scaled (scaled to coarser scale/resolution with evenly sized areas) or rezoned (scaled to the coarser scale/resolution with differently sized areas) (Ho et al. 2015; Mas et al. 2015). We use the term zoning to point out problems related to both scaling and rezoning effects. So far, few studies have examined the uncertainties that arise from the spatially aggregated data used for socioeconomic vulnerability or risk index preparation. As an exception, Ho et al. (2015) showed mismatches in combining exposure and vulnerability maps can cause problems related to MAUP. On the other hand, Rothlisberger et al. (2017) compared different data aggregation techniques, when mapping flood exposure but they did not map vulnerability, and Kienberger et al. (2009) and Lang et al. (2014) tried to form optimal areal units that do not follow administrative boundaries.

In addition to the spatial uncertainties, the vulnerability and risk maps may differ based on other choices in map production. Multiple studies have compared different indicator weighting options (Feizizadeh and Kienberger 2017; Reckien 2018; Schmidtlein et al. 2008; Tate 2012; Wiréhn et al. 2015). It has been suggested in various studies that local indicator weighting together with stakeholders helps in fitting the more general indices to the local context (Kazmierczak 2015; Preston et al. 2011; Reckien 2018; Rød et al. 2015). Further options include data transformation and normalization techniques (Tate 2012). For instance, Reckien (2018) compared area-based (i.e., number of people in an area) and population-based (i.e., proportion of population in an area) normalization of data. Also, the chosen indicator set and indicator selection method has an impact on the final maps (Feizizadeh and Kienberger 2017; Mainali and Pricope 2017; Tate 2012). Reckien (2018) compared additive indicator selection with reductionist selection. In the former, input data consists of those variables that either very likely affect vulnerability or have shown to affect vulnerability (Lee 2014; Reckien 2018). In the latter, a large number of potential variables are reduced to a smaller set by a statistical technique, such as principal component analysis (Lee 2014; Reckien 2018). Within principal component analysis, several component selection and weighting methods have also been evaluated (Schmidtlein et al. 2008; Tate 2012). Moreover, different visualization options have been compared. Wiréhn et al. (2015) showed how quintile-based visualization differs from equal intervals and discussed how different options can be used in different purposes. However, de Groot-Reichwein et al. (2018) did a more comprehensive survey on different visualization options and suggested that single-map presentations are preferred by stakeholders. Finally, there are uncertainties caused by future changes; in other words, spatial pattern and of degree of vulnerability and risk are dynamic. However, although climate change vulnerability and risk assessments should look toward future (Hinkel 2011), assessments are usually static (Jurgilevich et al. 2017). Therefore, assessments could include projections about future changes using multiple different methods (Jurgilevich et al. 2017).

Overall, the uncertainties caused by other methodological choices are seldom accounted for in vulnerability and riskmapping approaches (Reckien 2018), and few have developed methods for illustrating map uncertainties using single maps which could be utilized by stakeholders. We concentrate on 
two factors causing uncertainty, zoning, and weighting, i.e., differences in spatial units of analysis and weights given to indicators when constructing the index. We do not intend to carry out a full sensitivity analysis of all factors causing uncertainties, but we concentrate on two major factors and demonstrate how sensitivity analysis could be incorporated into map production by simple techniques. In the context of UHI vulnerability and risk in the Helsinki metropolitan area in southern Finland, we (1) assess the differences in vulnerability and risk maps caused by different zoning and weighting alternatives and (2) demonstrate how color-based visualization (hue and saturation) and composite maps (average and standard deviation) could pave the way for visualizing and assessing uncertainties in risk and vulnerability indices.

\section{Materials and methods}

\section{Study area}

Our study area consists of Helsinki, Espoo, and Vantaa municipalities in Helsinki metropolitan area $\left(60^{\circ} 07^{\prime}-60^{\circ} 24^{\prime} \mathrm{N}\right.$, $24^{\circ} 30^{\prime}-25^{\circ} 15^{\prime} \mathrm{E}$ ). The overall population of these municipalities is 1.14 million, which is about $20 \%$ of the Finnish population. The study area includes densely and sparsely built residential areas, industrial and commercial areas, agricultural areas, and forests. The population density of the study area is 1490 per $\mathrm{km}^{2}$. Although the study area is located in temperate zone with reasonably cool climate, UHI and heat waves during summer months are one of the key climatic and weather hazards in the area (Ruuhela et al. 2017), and they have been emphasized in climate change adaptation plans (Helsinki Region Environmental Services Authority 2016a).

\section{Data sources}

We acquired vulnerability and exposure data from Statistics Finland (2018), from the Cities of Helsinki, Vantaa and Espoo (Aluesarjat 2018), and Helsinki Region Environmental Services Authority (2016b, 2017). All the vulnerability and exposure datasets were from year 2015 or 2016. For mapping the hazard, we used two USGS Landsat 8 satellite images from years 2014 and 2015.

\section{Mapping risk components}

Using the nomenclature from the latest IPCC reports (IPCC 2014), we separate vulnerability from risk. Climate risk is composed of hazard (climatic phenomenon and its spatial configuration; in our case, heat wave), exposure (the elements that are under risk in specific locations; i.e., population), and vulnerability (characteristics of the exposed elements, i.e., socioeconomic characteristics of the population). In assessing vulnerability, only socioeconomic data is included and vulnerability maps show the pre-existing conditions (c.f. Joakim et al. 2015) in specific neighborhoods, while risk maps highlight the locations for combination of high vulnerability, exposure, and hazard. It has been discussed that area-based estimates of vulnerability (person $/ \mathrm{km}^{2}$ ) provide the most plausible and robust maps and emphasize areas with a large number of vulnerable inhabitants, but population-based estimates (\% of vulnerable population) indicate areas with high relative social vulnerability (Reckien 2018). We chose to combine population-based vulnerability data with area-based exposure data.

\section{Choosing vulnerability determinants}

We decided to use an additive method for indicator selection, as it has been shown that it is easier to interpret and is usually preferred by stakeholders (Reckien 2018). We chose eight different determinants that were drawn with the help of a literature review: childhood, elderly, gender, ill-health, low income, low level of education, immigration, and poor social networks (Table 1), which can be divided into endogenous and exogenous factors (c.f. Hinkel 2011). Said determinants correspond to the set of most significant indicators affecting individual's vulnerability, as identified by Lee (2014) based on their comprehensive literature review on the topic, and have been frequently used in the field (Preston et al. 2011). Of these determinants, all but gender and immigration have also been previously identified as particularly relevant factors influencing individuals' vulnerability in Helsinki metropolitan area (Kazmierczak 2015). Inclusion of immigration as a determinant of vulnerability in the present study was justified by both its role being highlighted in the literature for the Nordics (Rød et al. 2012) and in the USA (Cutter et al. 2003). A connection between gender and vulnerability has also been established in the literature (Preston et al. 2011). Due to lack of suitable data, we could not construct a suitable indicator for the ill-health determinant. For the other determinants, we used indicators shown in Table 1.

\section{Weighting of vulnerability determinants}

We weighted the indicators based on a Delphi evaluation (Helmer-Hirschberger 1967; Linstone and Turoff 1975). In the Delphi method, an expert group assigns subjective weights on different determinants (Brooks et al. 2005; El-Zein and Tonmoy 2015; Hinkel 2011; Kumpulainen 2006). We selected a panel to represent the sectors that have to deal with climate change impacts in relation to individual vulnerability specifically. The participants included representatives from the following sectors: electricity distribution, water works, food, public transport, and health care. These reflect the categorization made by the Ministry of Agriculture and Forestry that 
Table 1 Chosen determinants divided into two types (endogenous physical characteristics and exogenous socioeconomic status of the individual), indicator for the determinant and justification for the determinant and indicator selection

\begin{tabular}{|c|c|c|c|c|}
\hline Type & Determinant & Justification for the determinant & Indicator & Justification for the indicator \\
\hline \multirow[t]{4}{*}{$\begin{array}{l}\text { Physical } \\
\text { characteristic }\end{array}$} & $\begin{array}{l}\text { Childhood } \\
\quad(<18 \text { years })\end{array}$ & $\begin{array}{l}\text { Childhood, often considered to be } \\
\text { between } 0 \text { and } 18 \text { years (Mokkink } \\
\text { et al. 2008), is one of the most impor- } \\
\text { tant vulnerability factors related to } \\
\text { weather-related stresses (Carnes et al. } \\
\text { 2014; Hajat et al. 2010). }\end{array}$ & $\begin{array}{l}\text { The proportion of children } \\
<18 \text { years over total } \\
\text { population }\end{array}$ & Indicator corresponds the determinant \\
\hline & $\begin{array}{l}\text { Elderly } \\
\qquad(\geq 65 \text { years })\end{array}$ & $\begin{array}{l}\text { Elderly ( } \geq 65 \text { years) suffer from health } \\
\text { conditions which may worsen due to } \\
\text { heat waves (Carnes et al. 2014; Hajat } \\
\text { et al. 2010). It has been estimated that } \\
\text { in most cities in Italy during } 2003 \text { heat } \\
\text { wave, } 94 \% \text { of the deaths that occurred } \\
\text { were those over } 74 \text { year olds (Conti } \\
\text { et al. 2005). Also, other studies have } \\
\text { reported that elderly are particularly } \\
\text { vulnerable to heat waves (e.g., Fouillet } \\
\text { et al. 2006). }\end{array}$ & $\begin{array}{l}\text { The proportion of residents } \\
\geq 65 \text { over total population }\end{array}$ & Indicator corresponds the determinant \\
\hline & Gender & $\begin{array}{l}\text { Gender does not appear to play a large } \\
\text { role in terms of heat stress with no } \\
\text { conclusive evidence yet (Basu 2009; } \\
\text { Ye et al. 2012). There are some bio- } \\
\text { logical differences, leading to women } \\
\text { being more vulnerable } \\
\text { (Kaciuba-Uscilko and Grucza 2001), } \\
\text { and in heat waves, a higher excess } \\
\text { mortality for women has been reported } \\
\text { (Fouillet et al. 2006). }\end{array}$ & $\begin{array}{c}\text { The proportion of women } \\
\text { over total population }\end{array}$ & Indicator corresponds the determinant \\
\hline & Ill-health & $\begin{array}{l}\text { Exposure to heat can exacerbate existing } \\
\text { health conditions, and vice versa, } \\
\text { health problems increase vulnerability } \\
\text { to heat (Hajat et al. 2010; Watts et al. } \\
\text { 2015) }\end{array}$ & No indicator & Lack of suitable data \\
\hline $\begin{array}{l}\text { Socioeconomic } \\
\text { status }\end{array}$ & $\begin{array}{l}\text { Weak } \\
\text { economic } \\
\text { status }\end{array}$ & $\begin{array}{l}\text { Relative poverty can result in social } \\
\text { exclusion from society, in terms of } \\
\text { practices, customs and activities } \\
\text { (Townsend 1979), and increase an in- } \\
\text { dividual's vulnerability (Gallie et al. } \\
\text { 2003). Low economic status can also } \\
\text { weaken the availability of information } \\
\text { and the use of technology (Cutter et al. } \\
\text { 2003). Moreover, those who are poorer } \\
\text { often take short-term coping measures, }\end{array}$ & $\begin{array}{l}\text { The proportion of } \\
\text { households which belong } \\
\text { to the two lowest income } \\
\text { deciles ( } \leq 16,466 € \text { yearly } \\
\text { income). }\end{array}$ & $\begin{array}{l}\text { The lowest income category has been } \\
\text { found to be a suitable indicator for } \\
\text { weak economic status (Kazmierczak } \\
\text { 2015). Household level low income } \\
\text { was highly positively correlated with } \\
\text { individual-level low income at postal } \\
\text { code zoning level (Pearson's } \mathrm{r} \text { 0.77), } \\
\text { and individual's economic status is of- } \\
\text { ten more determined by the household } \\
\text { income rather than personal income. }\end{array}$ \\
\hline
\end{tabular}

such as sale of assets, which may increase longer term vulnerability (Tanner and Mitchell 2008). Some adaptation measures, such as insurance, are often not accessible to poorer people (Powell 2009).

Low level of Low level of education correlates closely education

Immigration with low socioeconomic status and health problems (Cutler and Lleras-Muney 2008; Galobardes et al. 2006). It has been shown that level of education largely determines one's economic status, and is strongly linked to one's working career (Galobardes et al. 2006). vulnerability, particularly in cases where language skills are low (Cutter
Immigration status may also increase
Proportion of adults $(\geq 18$ years) who have completed only basic level studies

The proportion of residents whose primary language is not Finnish or Swedish
In the Finnish context, basic level studies can be regarded as low level of education (Kazmierczak 2015).

Language barrier can be considered the most important factor increasing immigrants' vulnerability (Cutter et al. 
Table 1 (continued)

\begin{tabular}{|c|c|c|c|c|}
\hline Type & Determinant & Justification for the determinant & Indicator & Justification for the indicator \\
\hline \multicolumn{4}{|c|}{ et al. 2003; Lee 2014; Rød et al. 2012). } & 2003; Lee 2014). \\
\hline & $\begin{array}{c}\text { Weak social } \\
\text { network }\end{array}$ & $\begin{array}{l}\text { During extreme weather events, strong } \\
\text { family ties (Browning et al. 2006) and } \\
\text { collective action (Adger 2003) reduce } \\
\text { vulnerability. The rate of heat-related } \\
\text { deaths have been observed to be lower } \\
\text { in neighborhoods that are considered to } \\
\text { be more close-knit (Klinenberg 2002). } \\
\text { People living alone have been reported } \\
\text { to be highly vulnerable to heat waves } \\
\text { (Fouillet et al. 2006). }\end{array}$ & The unemployment rate & $\begin{array}{l}\text { Unemployment has been found to } \\
\text { correlate with social isolation } \\
\text { (Kieselbach 2003). }\end{array}$ \\
\hline
\end{tabular}

have been identified as sectors to be directly impacted by climate change (Sorvali 2013) with a specific emphasis on Helsinki and individual vulnerability. The selection of experts was further motivated by the identified need to integrate social vulnerability studies with sectoral vulnerability studies in order to map vulnerability comprehensively (Holsten and Kropp 2012). Such an integrative approach is novel and thus particularly relevant in the context of heat waves in Helsinki Metropolitan area, where the typically cool climate and the relatively high operational reliability of critical services have perhaps led to the marginalization of this nevertheless crucial area of vulnerability research.

As opposed to a traditional Delphi, the selected panel did not attempt to reach a consensus but was identifying the relative importance of each determinant based on their own sector. The Delphi consisted of two rounds at the end of 2015 and spring 2016. The first round was a semi-structured interview (DiCicco-Bloom and Crabtree 2006), including five sectorspecific sessions, conducted individually or in pairs with nine interviewed experts. The interview guide followed the conceptualization of climate vulnerability and risk, aiming to establish the specific ways in which the chosen determinants contribute to heightened individual vulnerability in relation to the climate change-induced malfunctions of the interviewees' respective sectors in Helsinki Metropolitan area. Specifically, interviewees were asked to reflect both upon the potential compromising effect heat waves and other extreme weather events might have on the service provided by their sector, and to predict how defects in said service might stress the adverse effects of heat waves on vulnerable individuals. The first round provided justifications and explanations to the second round of the Delphi, consisting of an electronic questionnaire, where the interviewees ranked the comparative importance of different determinants in relation to heat waves and individual vulnerability. The scale was from 1 to 8 , with the highest value indicating the most important determinant. This type of ranking has been commonly used in vulnerability research (Brooks et al. 2005; El-Zein and Tonmoy 2015;
Hinkel 2011; Kumpulainen 2006). The questionnaire was sent to nine respondents over e-mail with a 2-week response period, and the response rate was 100\% (Table S1).

\section{Zoning vulnerability determinants}

We used five different zoning options when mapping vulnerability. First four options were different statistical areas used by the cities, called here small (297 zones, average area $\left.2.6 \mathrm{~km}^{2}\right)$, medium $\left(120,6.4 \mathrm{~km}^{2}\right)$, large $\left(22,34.7 \mathrm{~km}^{2}\right)$, and municipality $\left(3,254.8 \mathrm{~km}^{2}\right)$. These four zonings were embedded into each other, so they shared the boundaries. In Vantaa, there was statistical data only for three areas (municipalities, large, small). We used the smallest administrative areas in Vantaa in both small and medium zoning option. The fifth option were the postal code areas (169 zones, $4.5 \mathrm{~km}^{2}$ ), which are used by the Statistics Finland. For all zonings, similar indicators were used.

\section{Hazard}

We calculated the spatial pattern of hazard using Landsat 8 data and land surface temperature (LST) in $30 \mathrm{~m}$ resolution. LST is measured through calculations of the brightness of the Earth's surface and are not directly correlated to air temperature (Tomlinson et al. 2011). Ground-based empirical measurements of air temperature are not usually used when mapping UHI because of the low resolution of available data. This is due to the lack of an extensive grid of physical measurement stations in urban areas (Buscail et al. 2012).

According to a comparison by $\mathrm{Yu}$ et al. (2014), a radiative transfer equation-based method using Landsat 8 band 10 was the most accurate LST-inversion method for Landsat 8; therefore, we selected it for the LST-conversion. In the method, band 10 values are first converted to top-of-atmosphere radiance and then to LST using an equation which takes into account surface emissivity, atmospheric transmittance, upwelling radiance, and downwelling radiance. We calculated 
land surface emissivity with the help of the image-specific normalized difference vegetation index values, and retrieved other parameter values from NASA's atmospheric correction parameter calculator [https://atmcorr.gsfc.nasa.gov/, (Barsi et al. 2003; Barsi et al. 2005)].

Previously, it has been shown how the spatial pattern of early summer and mid-summer heat waves differ in coastal cities such as Helsinki (Hjort et al. 2016). The water mass in the sea slowly warms during the summer months, and there is a clear difference between June and July (Hjort et al. 2016). Hence, we chose two Landsat 8 images representing early summer (July 3, 2015, path 189/row 18) and mid-summer (July 25, 2014, path 188/row 18). The 2015 image was taken on the third hot day of the summer, whereas the 2014 image was taken after 3 weeks of high temperatures. According to weather observations by the Finnish Meteorological Institute, both dates were classified as hot days (temperature over $25^{\circ} \mathrm{C}$ ). We calculated average temperature in Celsius over the two LST-images.

\section{Construction of indices}

We generated 11 different weighting options for the vulnerability indices: no weighting, weighting based on weights given by nine individual respondents, and average weights over individual respondent values. In addition, we tested five different zoning options. Therefore, we compared 55 different (five zonings and 11 weightings) vulnerability and risk indices.

We mapped exposure by calculating the amount of people in $250 \mathrm{~m}$ grid cells (Fig. S1a). We did not use cells with population of less than five people. In order to make different datasets comparable, we resampled vulnerability and hazard (Fig. S1b) maps to the $250 \mathrm{~m}$ grid cells, which corresponded to the exposure layer. The scaling of the vulnerability and hazard maps could potentially cause some uncertainties, because within each $250 \mathrm{~m}$ grid cells, multiple values for vulnerability or hazard can be found. We tested the degree of certainty by calculating the standard deviation of temperature (i.e., hazard) and unweighted vulnerability index values within each grid cell. The average standard deviation in temperature values over all grid cells was $1.1^{\circ} \mathrm{C}$ for both temperature images. The average standard deviation for vulnerability indices ranged between 0.0 (index with municipality zoning) and 0.1 (index with small zoning; index values ranged between 2.08 and 5.31). Based on this analysis, we judged that uncertainties caused by resampling were small.

We removed grid cells which did not have data for one or multiple layers from the analysis, and the final set consisted of 5480 grid cells. We normalized hazard, exposure, and vulnerability indicator values by dividing the values by the maximum grid cell value of each indicator (Reckien 2018; Yoon 2012). When calculating the vulnerability indices, we summed indicator values to form a final index. For risk indices, we normalized the summed vulnerability index values by dividing them by the maximum value and then summed vulnerability with normalized hazard and exposure values.

\section{Map comparison and sensitivity analysis}

When comparing the different indices, we calculated Pearson correlation coefficients ( $r$ ) between the different maps. Correlation analysis quantifies the similarity between two maps, and it has previously been used to analyze differences between different vulnerability maps (Yoon 2012). Additionally, we constructed consensus and certainty maps. We built the consensus map by calculating the average vulnerability/risk over all 55 vulnerability/risk indices in each grid cells, whereas we calculated the standard deviation of the 55 vulnerability/risk indices in each grid cell to get the certainty map. These two maps show together the most plausible approximation of vulnerability/risk in each grid cell and the certainty related to the approximation.

We visualized maps using quintiles, which divide grid cells into five categories having equal number of cells (Wiréhn et al. 2015). Hence, quintile visualization shows patterns of relative vulnerability or risk, which is often more important than absolute showing absolute values (Nelson et al. 2015). When constructing the composite consensus-certainty map, we visualized consensus map quintiles with different hue options (i.e., color) and certainty map quintiles with saturation (i.e., brightness of the color).

\section{Results}

\section{Weighting of indices}

According to the Delphi, old age, health, and childhood were the most significant factors when it comes to individual vulnerability to heat waves in Helsinki (Table 2). In particular, those of advanced age were considered to be vulnerable to disruptions in critical services, water, and electricity, also due to lower physical health and reduced mobility. Migration and gender were not considered to be as significant as the other determinants. However, in the interviews, the issue of language barriers was raised several times, due to many critical public warnings and announcements being provided in Finnish and Swedish only. Furthermore, some interviewees discussed how vulnerability of women is increased by their lower car ownership and resulting heavier reliance on public transportation services. The interviewees raised also more detailed sector-specific concerns. For example, public transportation experts raised concerns regarding the increased heat stress passengers are exposed to in older, non-airconditioned transport vehicles during heat waves, and the 
Table 2 Average value $(\mu)$, standard deviation $(\sigma)$ and range of the values of the Delphi-based urban heat island related vulnerability determinant weighting based on answers from 9 experts. Highest value (8) was given to the most important determinant

\begin{tabular}{lllllllll}
\hline Metric & Childhood & Elderly & Gender & $\begin{array}{l}\text { Ill- } \\
\text { health }\end{array}$ & $\begin{array}{l}\text { Weak } \\
\text { economic } \\
\text { status }\end{array}$ & $\begin{array}{l}\text { Low level } \\
\text { of } \\
\text { education }\end{array}$ & Immigration & $\begin{array}{l}\text { Weak } \\
\text { social } \\
\text { network }\end{array}$ \\
\hline$\mu$ & 5.9 & 7.4 & 1.9 & 7.2 & 4.8 & 3.0 & 2.1 & 3.7 \\
$\sigma$ & 0.9 & 0.5 & 1.4 & 1.1 & 1.3 & 0.7 & 1.5 & 1.0 \\
Range & $4-7$ & $7-8$ & $1-5$ & $5-8$ & $2-6$ & $2-4$ & $1-5$ & $2-5$ \\
\hline
\end{tabular}

possibility of thermal expansion of railways hindering the use of rail transport. In turn, experts of electricity distribution and water works noted how disruptions in their services during a heat wave might significantly increase the vulnerability of individuals particularly prone to dehydration and heat stress, such as the elderly.

\section{Differences between maps}

There were large differences in the vulnerability maps caused by different zonings (Table 3; Fig.1a, b). The maps using municipal boundaries had low correlations with the maps using smaller administrative units, but the differences between the three smallest administrative units (small, medium, postal) were relatively small (Table 3). Large administrative units had higher correlations with smaller administrative units than with municipalities, but overall, their correlations with other maps were relatively low. The differences caused by changing administrative boundaries were notably smaller in risk maps (Table 3; Fig. 1c, d) than in vulnerability maps. There was relatively little

Table 3 The range in Pearson correlation coefficient values in different map vulnerability and risk map comparisons. Comparison was conducted between all vulnerability/risk maps, between zoning options, between weighting options, or between average maps and other maps. When different zoning options were compared, weighting option was similar in the compared maps. Vice versa, when comparing weighted maps against unweighted maps, zoning option was similar in the compared maps. All correlations were statistically significant $(P$ value $<0.0001)$

\begin{tabular}{llrl}
\hline Comparison 1 & Comparison 2 & Vulnerability & \multicolumn{1}{l}{ Risk } \\
\hline All & All & $-0.02-1.00$ & $0.83-1.00$ \\
Municipal & Large & $0.14-0.41$ & $0.86-0.93$ \\
Municipal & Medium & $0.03-0.31$ & $0.85-0.91$ \\
Municipal & Small & $0.08-0.29$ & $0.84-0.89$ \\
Municipal & Postal & $0.11-0.30$ & $0.83-0.89$ \\
Large & Medium & $0.62-0.64$ & $0.90-0.94$ \\
Large & Small & $0.50-0.53$ & $0.86-0.91$ \\
Large & Postal & $0.60-0.62$ & $0.88-0.93$ \\
Medium & Small & $0.79-0.82$ & $0.94-0.96$ \\
Medium & Postal & $0.72-0.75$ & $0.92-0.95$ \\
Small & Postal & $0.73-0.74$ & $0.92-0.95$ \\
Weighted & Unweighted & $0.62-1.00$ & $0.96-1.00$ \\
Average & All & $0.16-0.90$ & $0.93-0.98$ \\
\hline
\end{tabular}

difference between weighted and unweighted vulnerability or risk maps when similar zoning was used (Fig. 1e, f).

\section{The consensus and certainty maps}

The consensus vulnerability and risk maps (Figs. 2a and 3a) had generally high correlations with maps using a single index only (Table 3). Nevertheless, in the vulnerability maps, the dissimilarities were high between municipal maps and consensus vulnerability maps (r $0.15-0.37$, Fig. S2). The certainty maps (Figs. 2b and 3b), drawn with the help of standard deviations, were similar for vulnerability and risk. When the certainties were combined with average risk or vulnerability scores, final maps showing the potential risk/vulnerability and its certainty could be constructed (Figs. 2c and 3c). Interestingly, some areas, such as Helsinki City Centre (shown in the bottom centre of the maps) had both low vulnerability and high risk, but at the same time, low certainty.

\section{Discussion}

We analyzed how the vulnerability and risk maps differ when different zoning and weighting options are used. We found that zoning has a large effect especially on the vulnerability maps but its effect on risk maps is smaller. Weighting had a smaller effect on the final maps. We also constructed consensus and certainty maps to visualize the certainty of vulnerability and risk maps and found that these maps showed their potential, for instance, in highlighting areas, which may have both high risk/vulnerability and high certainty for risk/vulnerability.

According to our results, weighting caused small differences in the final maps, which is in contrast with the results obtained by Wiréhn et al. (2015) and Reckien (2018). In our analysis, the range of weights was $1-8$, which has an effect on the results. Giving heavier weight to most relevant indicators could have altered the picture. For instance, in the work by Reckien (2018), weights ranged between 1 and 21. There are also other weighting options than multiplying indicator values. For instance, Wiréhn et al. (2015) combined three different weighting options based on principal components analysis with three different summarization techniques. Overall, it is perhaps more important to show and discuss 
Fig. 1 a Unweighted vulnerability map drawn with small administrative boundaries. b Unweighted vulnerability map with municipal boundaries. c Unweighted risk map with small administrative boundaries. $\mathbf{d}$ Unweighted risk map with municipal boundaries. $\mathbf{e}$ Unweighted vulnerability map with postal boundaries. $\mathbf{f}$ Weighted vulnerability map with postal boundaries. Maps are divided into quintiles, but for map b only three values are shown as there are three municipalities
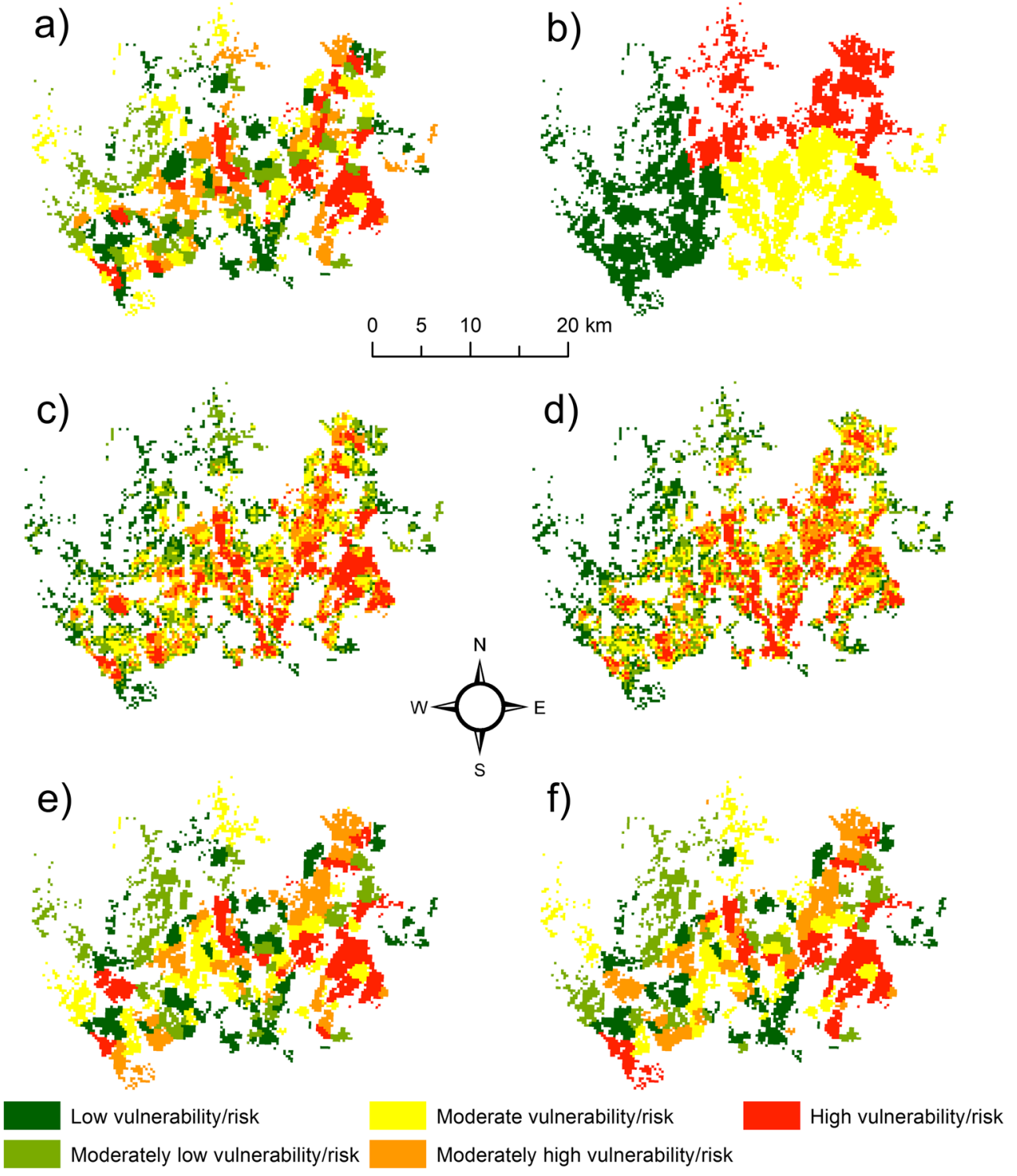

how the weighting alters final maps than trying to find out the best method for weighting. In the puzzle of setting weights, different visualization tools used in wider stakeholder processes (Bohman et al. 2015; Carter et al. 2016; Rød et al. 2015; Wirehn et al. 2017) may also help, especially if one considers that vulnerability mapping is a learning process, rather than considering the final maps as the most important product. It is also possible to include processes of validation and negotiation into the stakeholder process when weighting indicators (Carter et al. 2016; Rød et al. 2015).

We found that when different zoning options are used, the spatial pattern of vulnerability may differ dramatically, which is in line with previous studies (Rothlisberger et al. 2017; Salmivaara et al. 2015). Especially in the vulnerability maps, the spatial pattern drawn with municipal boundaries was too coarse, as there was considerable intra-municipal variation. Additionally, vulnerability maps using municipal boundaries, or the large zoning option, were also quite different from the maps using smaller units. This questions the usefulness of vulnerability and risk maps that use municipalities or even larger areal units as the basic unit, which have been used quite widely in index-based studies (e.g., Carter et al. 2016; Rød et al. 2015).

It has been argued that spatial units should be preferably very small as there is fine-scale variation in the spatial patterns of risk components (Nelson et al. 2015). In our smallest zoning option, the average size of one zone is $2.6 \mathrm{~km}^{2}$ and the average population nearly 4000. In earlier studies in Helsinki metropolitan area, it has been found that there is a clear trend in social segregation when evaluated using $250 \mathrm{~m}$ grid, but this trend is not visible when analyzed using smallest statistical zones (Kortteinen and Vaattovaara 2015). We could not use the grid data in our research due to its high cost, but it can be questioned whether the spatial pattern in vulnerability would differ, if grid data instead of statistical zone data would 
Fig. 2 a Average vulnerability (i.e., consensus map) over 50 different vulnerability maps divided into quintiles. b Certainty divided into quintiles. Standard deviation of the 50 vulnerability index values is used as a proxy for certainty. c Combined map of a and $\mathrm{b}$; both consensus and certainty are divided into quintiles and thus there are 25 classes a)

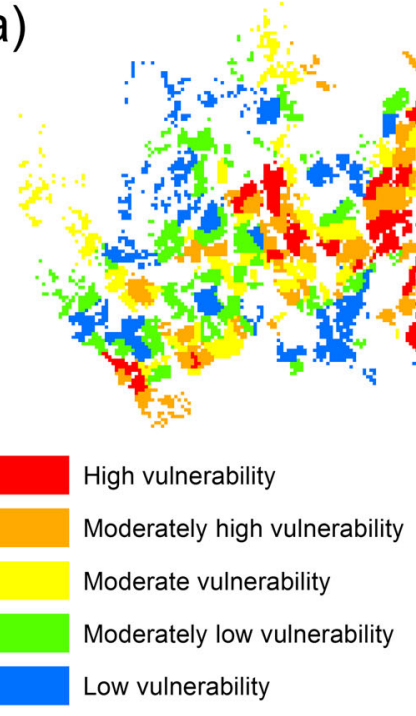

b)

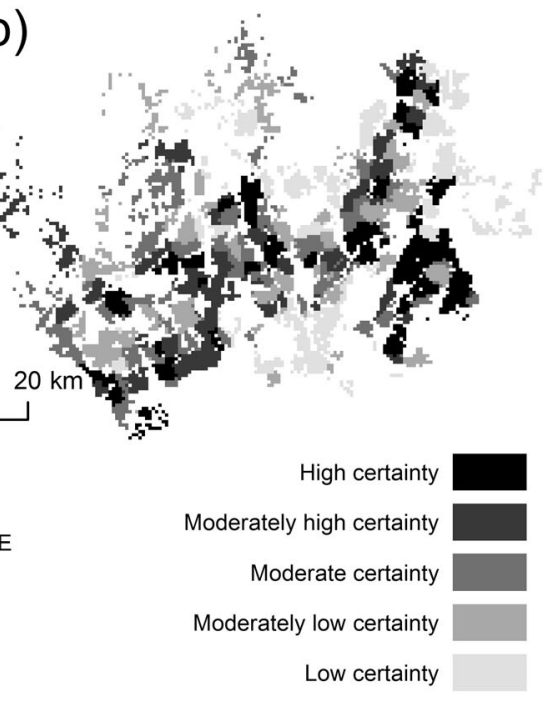

c)

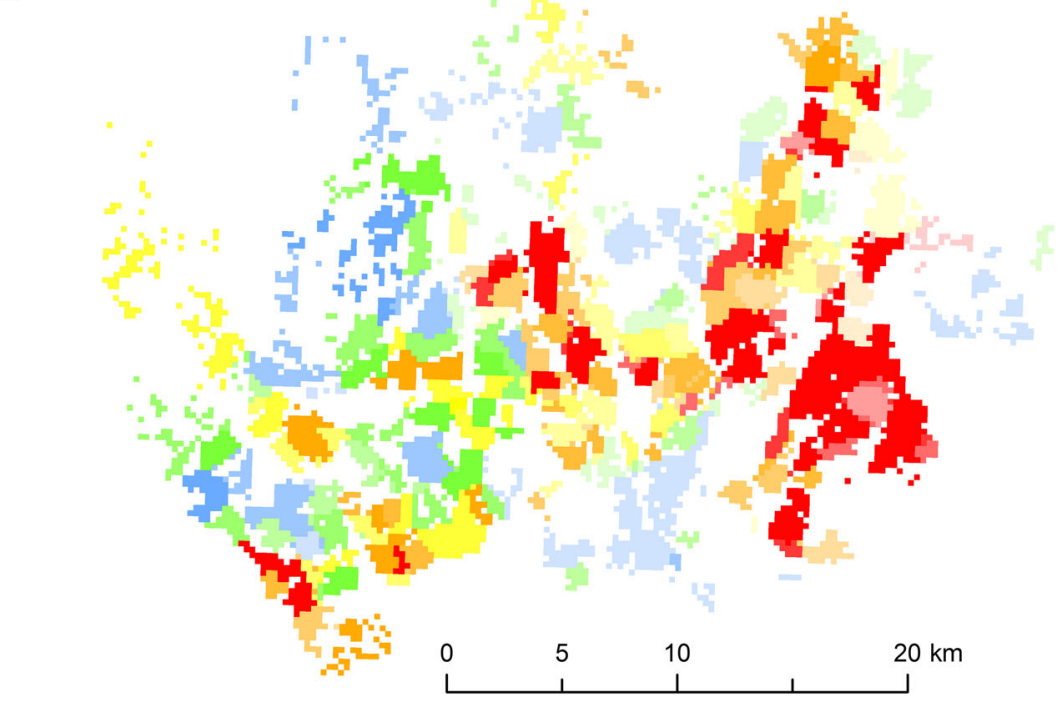

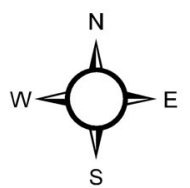

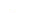

High vulnerability, high certainty

Moderately high vulnerability, high certainty

Moderate vulnerability, high certainty

Moderately low vulnerability, high certainty

Low vulnerability, high certainty 
Fig. 3 a Average risk (i.e., consensus map) over 50 different vulnerability maps divided into quintiles. b Certainty divided into quintiles. Standard deviation of the 50 risk index values is used as a proxy for certainty. $\mathbf{c}$ Combined maps of $\mathbf{a}$ and $\mathbf{b}$; both consensus and certainty are divided into quintiles and thus there are 25 classes a)

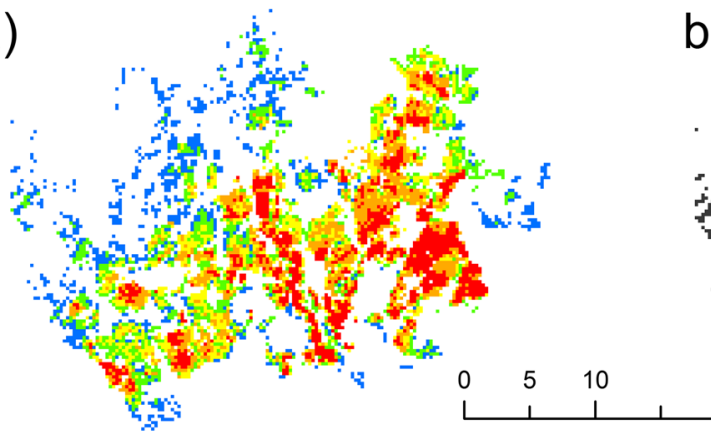

b)

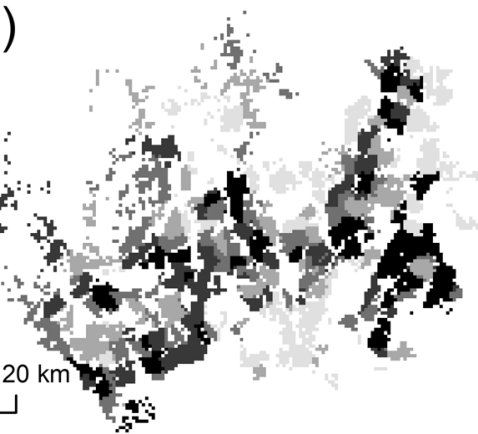

High certainty

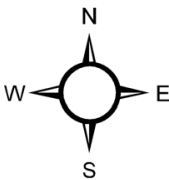

High certainty

Moderately high certainty

Moderate certainty

Moderately low certainty

Low certainty

c) Moderately low risk

Low risk

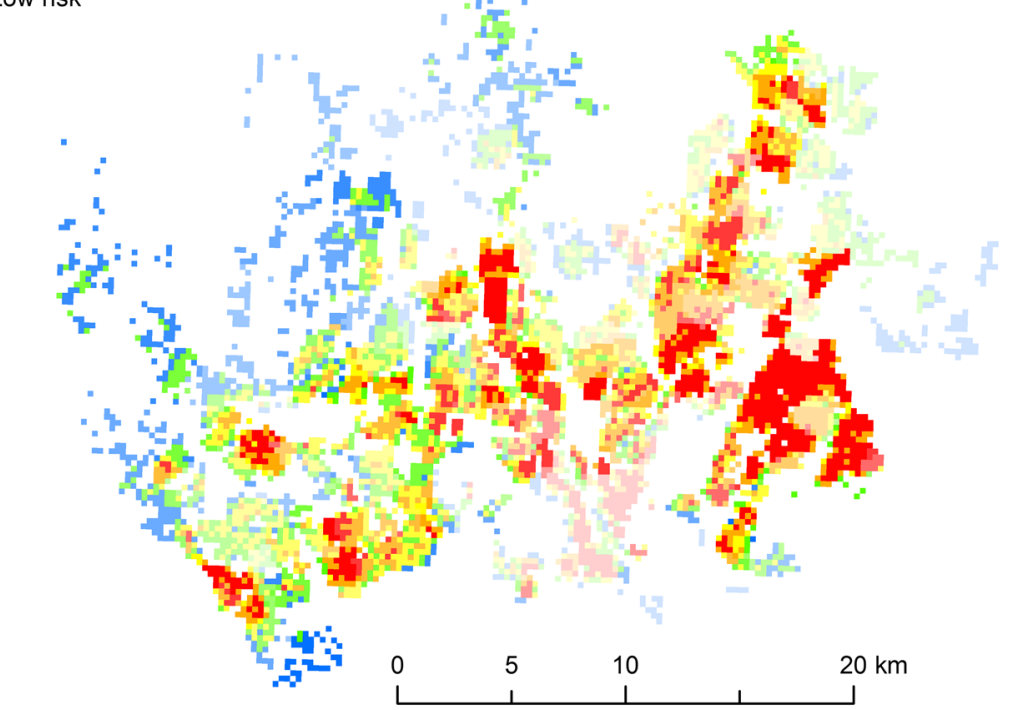

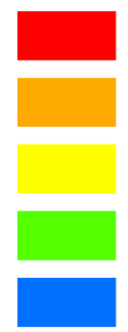

High risk, high certainty

Moderately high risk, high certainty

Moderate risk, high certainty

Moderately low risk, high certainty

Low risk, high certainty
High risk, low certainty

Moderately high risk, low certainty

Moderate risk, low certainty

Moderately low risk, low certainty

Low risk, low certainty have highest population density and high vulnerability. However, if the social structure is not uniform, the method highlights only the areas which have high population density. It has been discussed earlier that areas with high population density might have high risk (Cutter et al. 2003; Reckien 2018). Hence, it could be argued that high spatial resolution hazard and exposure maps could be combined with vulnerability maps having any reasonable spatial resolution. Alternatively, vulnerability maps could show the amount of vulnerable population. In this case, choices in map production such as weighting, indicator selection and data normalization affect the final maps less than when vulnerability maps show the proportion of vulnerable population (Reckien 2018). In addition to population data, there are other data options in downscaling vulnerability, such as cadastral data (Nelson et al. 2015).

Our approach complements previous approaches dealing with modifiable areal unit problem (MAUP). The main asset of our methods is the fact that consensus and certainty maps fuzzify the vulnerability and risk maps and help in pointing out the differences between maps. Our approach is also in some ways beneficial to earlier methods, which have analyzed and mitigated MAUP. For instance, the Getis-Ord spatial autocorrelation 
statistics can be used in identifying hotspots (Ho et al. 2015; Rothlisberger et al. 2017). In Getis-Ord, a single map should be used as a starting point. This restricts the use of the method in analyzing uncertainties and differences between different mapping options. Therefore, Getis-Ord can be thought to be a merely an advanced visualization technique in finding spatial trends. Another question is that whether spatial autocorrelation, which is analyzed in the Getis-Ord, is a relevant phenomenon for climate risk and vulnerability. On the one hand, Getis-Ord can reveal spatial clusters in which vulnerability or risk is high on a larger area. On the other hand, it may underestimate risk on risky areas with small spatial extent located within areas with low risk. The problems with Getis-Ord are also evident in the geon approach in which optimal vulnerability units are formed by aggregating spatial data into homogenous regions based on grid cell-specific indicator values (Kienberger et al. 2009; Lang et al. 2014). Also, in the geons, a single final map is presented, which should then be the optimal map for vulnerability or risk. The main asset in geons is that administrative or statistical boundaries that are often arbitrary when looking at risk and vulnerability are replaced with more meaningful boundaries, which ideally should reflect the spatial pattern in risk and vulnerability. However, both Getis-Ord and geon approach would benefit from analysis of uncertainties in the input data including how different choices in indexproduction such as weighting affect the maps.

\section{Conclusion}

Given the increasing need to use maps in adaptation planning, it is clear from our analysis that there is a need to address the uncertainties related to the data used, as well as the method. We show how weighting and especially zoning can have a large effect on vulnerability and risk maps. In addition, there are also other options in map production such as indicator selection, data normalization, and visualization which have effects on the final maps, and sensitivity analyses assess the uncertainties evident in every map-making process.

We argue that there is a need to move from crisp vulnerability maps to maps that also show the uncertainties in the maps. Instead of showing just one value for risk/vulnerability in each location, several possible vulnerability/risk values and uncertainties related to the values should be shown. We show how simple techniques using maps of consensus and certainty help in this. The maps of certainty could help policy-makers and other stakeholders in understanding the probability of vulnerability and could thus help to facilitate more critical use of maps. Furthermore, they would increase the credibility and trustworthiness of the maps. Therefore, we urge that focus in vulnerability and risk mapping should be in map-making process instead of final maps showing "certain" vulnerability and risk hot spots. One final map can be misleading or even erroneous, and a bunch of possible maps show the nature of vulnerability and risk more realistically. On the other hand, stakeholders often prefer simple and single maps (de GrootReichwein et al. 2018; Reckien 2018), and thus there should also be methodological development to visualize maps so that uncertainties can be showed understandably to various stakeholders. Finally, sensitivity analyses are of utmost importance when mapping future climate risks, because there is deep uncertainty in future spatial patterns of different risk components, especially vulnerability (Jurgilevich et al. 2017).

Funding Open access funding provided by University of Helsinki including Helsinki University Central Hospital.

Open Access This article is distributed under the terms of the Creative Commons Attribution 4.0 International License (http:// creativecommons.org/licenses/by/4.0/), which permits unrestricted use, distribution, and reproduction in any medium, provided you give appropriate credit to the original author(s) and the source, provide a link to the Creative Commons license, and indicate if changes were made.

\section{References}

Abrahamson V, Wolf J, Lorenzoni I, Fenn B, Kovats S, Wilkinson P, Adger WN, Raine R (2009) Perceptions of heatwave risks to health: interview-based study of older people in London and Norwich, UK. J Public Health 31:119-126. https://doi.org/10.1093/pubmed/fdn102

Adger WN (2003) Social aspects of adaptive capacity. In: Smith J, Klein R, Huq S (eds) Social aspects of adaptive capacity. Imperial College Press, London, pp 29-49. https://doi.org/10.1142/9781860945816_0003

Aluesarjat (2018) Helsingin seudun aluesarjat. The municipalities of the Helsinki Capital Region. http://www.aluesarjat.fi. Accessed 30 March 2019

Barsi JA, Barker JL, Schott JR (2003) An atmospheric correction parameter calculator for a single thermal band earth-sensing instrument. In: International Geoscience and Remote Sensing Symposium (IGARSS). pp 3014-3016. https://doi.org/10.1109/ IGARSS.2003.1294665

Barsi JA, Schott JR, Palluconi FD, Hook SJ (2005) Validation of a webbased atmospheric correction tool for single thermal band instruments. In: Proceedings of SPIE - The International Society for Optical Engineering. pp 1-7. https://doi.org/10.1117/12.619990

Basu R (2009) High ambient temperature and mortality: a review of epidemiologic studies from 2001 to 2008. Environ Health: Glob Access Sci Sour 8. https://doi.org/10.1186/1476-069X-8-40

Bohman A, Neset TS, Opach T, Rød JK (2015) Decision support for adaptive action - assessing the potential of geographic visualization. J Environ Plan Manag 58:2193-2211. https://doi.org/10.1080/ 09640568.2014.973937

Borgonovo E, Plischke E (2016) Sensitivity analysis: a review of recent advances. Eur J Oper Res 248:869-887. https://doi.org/10.1016/j. ejor.2015.06.032

Brooks N, Adger WN, Kelly PM (2005) The determinants of vulnerability and adaptive capacity at the national level and the implications for adaptation. Glob Environ Chang 15:151-163. https://doi.org/10. 1016/j.gloenvcha.2004.12.006

Browning CR, Wallace D, Feinberg SL, Cagney KA (2006) Neighborhood social processes, physical conditions, and disaster-related mortality: the case of the 1995 Chicago heat wave. Am Sociol Rev 71:661-678. https://doi.org/10.1177/000312240607100407

Buscail C, Upegui E, Viel JF (2012) Mapping heatwave health risk at the community level for public health action. Int J Health Geogr 11. https://doi.org/10.1186/1476-072x-11-38 
Carnes BA, Staats D, Willcox BJ (2014) Impact of climate change on elder health. J Gerontol A Biol Sci Med Sci 69:1087-1091. https:// doi.org/10.1093/gerona/glt159

Carter TR, Fronzek S, Inkinen A, Lahtinen I, Lahtinen M, Mela H, O'Brien K, Rosentrater LD, Ruuhela R, Simonsson L, Terama E (2016) Characterising vulnerability of the elderly to climate change in the Nordic region. Reg Environ Chang 16:43-58. https://doi.org/ 10.1007/s10113-014-0688-7

Conti S, Meli P, Minelli G, Solimini R, Toccaceli V, Vichi M, Beltrano C, Perini L (2005) Epidemiologic study of mortality during the summer 2003 heat wave in Italy. Environ Res 98:390-399. https://oi.org/ 10.1016/j.envres.2004.10.009

Cutler D, Lleras-Muney A (2008) Education and health: evaluating theories and evidence. In: Schoeni RF, House JS, Kaplan GA, Pollack $\mathrm{H}$ (eds) Making Americans healthier: social and economic policy as health policy. Russell Sage Foundation, New York, pp 29-61. https://doi.org/10.3386/w12352

Cutter SL, Boruff BJ, Shirley WL (2003) Social vulnerability to environmental hazards. Soc Sci Q 84:242-261. https://doi.org/10.1111/ 1540-6237.8402002

de Groot-Reichwein MAM, van Lammeren RJA, Goosen H, Koekoek A, Bregt AK, Vellinga P (2018) Urban heat indicator map for climate adaptation planning. Mitig Adapt Strateg Glob Chang 23:169-185. https://doi.org/10.1007/s11027-015-9669-5

DiCicco-Bloom B, Crabtree BF (2006) The qualitative research interview. Med Educ 40:314-321. https://doi.org/10.1111/j.1365-2929. 2006.02418.x

El-Zein A, Tonmoy FN (2015) Assessment of vulnerability to climate change using a multi-criteria outranking approach with application to heat stress in Sydney. Ecol Indic 48:207-217. https://doi.org/10. 1016/j.ecolind.2014.08.012

Feizizadeh B, Kienberger S (2017) Spatially explicit sensitivity and uncertainty analysis for multicriteria-based vulnerability assessment. J Environ Plan Manag 60:2013-2035. https://doi.org/10.1080/ 09640568.2016.1269643

Ferretti F, Saltelli A, Tarantola S (2016) Trends in sensitivity analysis practice in the last decade. Sci Total Environ 568:666-670. https:// doi.org/10.1016/j.scitotenv.2016.02.133

Fotheringham AS, Wong DWS (1991) The modifiable areal unit problem in multivariate statistical analysis. Environ Plan A 23:1025-1044. https://doi.org/10.1068/a231025

Fouillet A, Rey G, Laurent F, Pavillon G, Bellec S, Guihenneuc-Jouyaux, Clavel J, Dougla E, Hémon D (2006) Excess mortality related to the August 2003 heat wave in France. Int Arch Occup Environ Health 80:16-24. https://doi.org/10.1007/s00420-006-0089-4

Gallie D, Paugam S, Jacobs S (2003) Unemployment, poverty and social isolation: is there a vicious circle of social exclusion? Eur Soc 5:132. https://doi.org/10.1080/1461669032000057668

Galobardes B, Shaw M, Lawlor DA, Lynch JW, Smith GD (2006) Indicators of socioeconomic position (part 1). J Epidemiol Community Health 60:7-12. https://doi.org/10.1136/jech.2004. 023531

Hajat S, O'Connor M, Kosatsky T (2010) Health effects of hot weather: from awareness of risk factors to effective health protection. Lancet 375:856-863. https://doi.org/10.1016/S0140-6736(09)61711-6

Helmer-Hirschberger O (1967) Analysis of the future: the Delphi method. RAND corporation, Santa Monica

Helsinki Region Environmental Services Authority (2016a) Pääkaupunkiseudun ilmastonmuutokseen sopeutumisen uudet haasteet. Helsinki Region Environmental Services Authority, Helsinki

Helsinki Region Environmental Services Authority (2016b) SeutuCD database https://www.hsy.fi/en/experts/regional-data/geographicinformation/Pages/SeutuCD.aspx. Accessed 30 March 2019

Helsinki Region Environmental Services Authority (2017) Population grid of Helsinki metropolitan area. Helsinki Region Infoshare.
https://hri.fi/data/en_GB/dataset/vaestotietoruudukko. Accessed 30 March 2019

Hinkel J (2011) "Indicators of vulnerability and adaptive capacity": towards a clarification of the science-policy interface. Glob Environ Change Hum Pol Dimens 21:198-208. https://doi.org/10.1016/j. gloenvcha.2010.08.002

Hjort J, Suomi J, Kayhko J (2016) Extreme urban-rural temperatures in the coastal city of Turku, Finland: Quantification and visualization based on a generalized additive model. Sci Total Environ 569:507517. https://doi.org/10.1016/j.scitotenv.2016.06.136

Ho HC, Knudby A, Huang W (2015) A spatial framework to map heat health risks at multiple scales. Int J Environ Res Public Health 12: 16110-16123. https://doi.org/10.3390/ijerph121215046

Holsten A, Kropp JP (2012) An integrated and transferable climate change vulnerability assessment for regional application. Nat Hazards 64:1977-1999. https://doi.org/10.1007/s11069-012-0147-z

Huang GL, Zhou WQ, Cadenasso ML (2011) Is everyone hot in the city? Spatial pattern of land surface temperatures, land cover and neighborhood socioeconomic characteristics in Baltimore, MD. J Environ Manag 92:1753-1759. https://doi.org/10.1016/j.jenvman.2011.02.006

IPCC (2014) Summary for policymakers. In: Field CB, Barros VR, Dokken DJ, Mach KJ, Mastrandrea MD, Bilir TE, Chatterjee M, Ebi KL, Estrada YO, Genova RC, Girma B, Kissel ES, Levy AN, MacCracken S, Mastrandrea PR, White LL (eds) Climate change 2014: impacts, adaptation, and vulnerability. Part A: Global and Sectoral Aspects. Contribution of Working Group II to the Fifth Assessment Report of the Intergovernmental Panel on Climate Change. Cambridge University Press, Cambridge, pp 1-32

Jeffery C, Ozonoff A, Pagano M (2014) The effect of spatial aggregation on performance when mapping a risk of disease. Int J Health Geogr. https://doi.org/10.1186/1476-072X-13-9

Joakim EP, Mortsch L, Oulahen G (2015) Using vulnerability and resilience concepts to advance climate change adaptation. Environ Hazards 14: 137-155. https://doi.org/10.1080/17477891.2014.1003777

Jurgilevich A, Räsänen A, Groundstroem F, Juhola S (2017) A systematic review of dynamics in climate risk and vulnerability assessments. Environ Res Lett 12. https://doi.org/10.1088/1748-9326/aa5508

Kaciuba-Uscilko H, Grucza R (2001) Gender differences in thermoregulation. Curr Opin Clin Nutr Metab Care 4:533-536. https://doi.org/ 10.1097/00075197-200111000-00012

Kazmierczak A (2015) Analysis of social vulnerability to climate change in the Helsinki metropolitan area. Helsinki Region Environmental Services Authority, Helsinki

Kienberger S, Lang S, Zeil P (2009) Spatial vulnerability units-expertbased spatial modelling of socio-economic vulnerability in the Salzach catchment, Austria. Nat Hazards Earth Syst Sci 9:767778. https://doi.org/10.5194/nhess-9-767-2009

Kieselbach T (2003) Long-term unemployment among young people: the risk of social exclusion. Am J Community Psychol 32:69-76. https://doi.org/10.1023/A:1025694823396

Klein Rosenthal J, Kinney PL, Metzger KB (2014) Intra-urban vulnerability to heat-related mortality in New York City, 1997-2006. Health Place 30:45-60. https://doi.org/10.1016/j.healthplace.2014.07.014

Klinenberg E (2002) Heat wave: a social autopsy of disaster in Chicago. The University of Chicago Press, Chicago

Kortteinen M, Vaattovaara M (2015) Segregaation aika. Yhteiskuntapolitiikka. 80:562-574

Kumpulainen S (2006) Vulnerability concepts in hazard and risk assessment. Natural and technological hazards and risks affecting the spatial development of European regions. Geological Survey of Finland, Espoo

Lang S, Kienberger S, Tiede D, Hagenlocher M, Pernkopf L (2014) Geons - domain-specific regionalization of space. Cartogr Geogr Inf Sci 41:214-226. https://doi.org/10.1080/15230406.2014. 902755 
Lee YJ (2014) Social vulnerability indicators as a sustainable planning tool. Environ Impact Assess Rev 44:31-42. https://doi.org/10.1016/ j.eiar.2013.08.002

Linstone HA, Turoff M (eds) (1975) The Delphi method: techniques and applications. Addison-Wesley Publishing Company, Don Mills

Lissner TK, Holsten A, Walther C, Kropp JP (2012) Towards sectoral and standardised vulnerability assessments: the example of heatwave impacts on human health. Clim Chang 112:687-708. https://doi. org/10.1007/s10584-011-0231-5

Luber G, McGeehin M (2008) Climate change and extreme heat events. Am J Prev Med 35:429-435. https://doi.org/10.1016/j.amepre.2008.08.021

Mainali J, Pricope NG (2017) High-resolution spatial assessment of population vulnerability to climate change in Nepal. Appl Geogr 82:6682. https://doi.org/10.1016/j.apgeog.2017.03.008

Mas JF, Vega AP, Reyes AA, Santiago MAC, Sandoval AF (2015) Assessing modifiable areal unit problem in the analysis of deforestation drivers using remote sensing and census data. In: International Archives of the Photogrammetry, Remote Sensing and Spatial Information Sciences - ISPRS Archives. pp 77-80. https://doi.org/ 10.5194/isprsarchives-XL-3-W3-77-2015

Mokkink LB, Van Der Lee JH, Grootenhuis MA, Offringa M, Heymans HSA (2008) Defining chronic diseases and health conditions in childhood (0-18 years of age): national consensus in the Netherlands. Eur J Pediatr 167:1441-1447. https://doi.org/10. 1007/s00431-008-0697-y

Nelson KS, Abkowitz MD, Camp JV (2015) A method for creating high resolution maps of social vulnerability in the context of environmental hazards. Appl Geogr 63:89-100. https://doi.org/10.1016/j. apgeog.2015.06.011

Oke TR (1982) The energetic basis of the urban heat island. Q J R Meteorol Soc 108:1-24. https://doi.org/10.1002/qj.49710845502

Openshaw S, Baxter RS (1977) Algorithm 3: a procedure to generate pseudo-random aggregations of $\mathrm{N}$ zones into $\mathrm{M}$ zones, Where $\mathrm{M}$ is Less Than N. Environ Plann A 9:1423-1428. https://doi.org/10. $1068 / \mathrm{a} 091423$

Páez A, Scott DM (2005) Spatial statistics for urban analysis: a review of techniques with examples. GeoJournal 61:53-67

Perveen S, James LA (2012) Changes in correlation coefficients with spatial scale and implications for water resources and vulnerability data. Prof Geogr 64:389-400. https://doi.org/10.1080/00330124.2011.609783

Powell S (2009) The health impacts of disasters: who is most at risk. Health Policy Research Bulletin 15:23-28

Preston BL, Yuen EJ, Westaway RM (2011) Putting vulnerability to climate change on the map: a review of approaches, benefits, and risks. Sustain Sci 6:177-202. https://doi.org/10.1007/s11625-011-0129-1

Reckien D (2018) What is in an index? Construction method, data metric, and weighting scheme determine the outcome of composite social vulnerability indices in New York city. Reg Environ Chang 18: 1439-1451. https://doi.org/10.1007/s10113-017-1273-7

Rød JK, Berthling I, Lein H, Lujala P, Vatne G, Bye LM (2012) Integrated vulnerability mapping for wards in mid-Norway. Local Environ 17: 695-716. https://doi.org/10.1080/13549839.2012.685879

Rød JK, Opach T, Neset TS (2015) Three core activities toward a relevant integrated vulnerability assessment: validate, visualize, and negotiate. J Risk Res 18:877-895. https://doi.org/10.1080/13669877. 2014.923027

Rothlisberger V, Zischg AP, Keiler M (2017) Identifying spatial clusters of flood exposure to support decision making in risk management. Sci Total Environ 598:593-603. https://doi.org/10.1016/j.scitotenv. 2017.03.216

Ruuhela R, Jylha K, Lanki T, Tiittanen P, Matzarakis A (2017) Biometeorological assessment of mortality related to extreme temperatures in Helsinki region, Finland, 1972-2014. Int J Environ Res Publ Health 14. https://doi.org/10.3390/ijerph14080944

Saisana M, Saltelli A, Tarantola S (2005) Uncertainty and sensitivity analysis techniques as tools for the quality assessment of composite indicators. J R Stat Soc A Stat Soc 168:307-323. https://doi.org/10. 1111/j.1467-985X.2005.00350.x

Salmivaara A, Porkka M, Kummu M, Keskinen M, Guillaume JHA, Varis O (2015) Exploring the modifiable areal unit problem in spatial water assessments: a case of water shortage in monsoon. Asia Water 7:898-917. https://doi.org/10.3390/w7030898

Schmidtlein MC, Deutsch RC, Piegorsch WW, Cutter SL (2008) A sensitivity analysis of the social vulnerability index. Risk Anal 28: 1099-1114. https://doi.org/10.1111/j.1539-6924.2008.01072.x

Sorvali J (2013) Ilmastonmuutoksen haitalliset vaikutukset ja toimialojen haavoittuvuus. Ministry of Agriculture and Forestry, Helsinki

Statistics Finland (2018) Paavo - Open data by postal code area. https:// www.stat.fi/tup/paavo/index en.html. Accessed 30 March 2019

Tanner T, Mitchell T (2008) Introduction: Building the case for pro-poor adaptation. IDS Bull 39:1-5

Tate E (2012) Social vulnerability indices: a comparative assessment using uncertainty and sensitivity analysis. Nat Hazards 63:325347. https://doi.org/10.1007/s11069-012-0152-2

Tomlinson CJ, Chapman L, Thornes JE, Baker CJ (2011) Including the urban heat island in spatial heat health risk assessment strategies: a case study for Birmingham, UK. Int J Health Geogr 10. https://doi. org/10.1186/1476-072x-10-42

Townsend P (1979) Poverty in the United Kingdom. Penguin, Harmondsworth

Watts N, Adger WN, Agnolucci P, Blackstock J, Byass P, Cai W, Chaytor S, Colbourn T, Collins M, Cooper A, Cox PM, Depledge J, Drummond P, Ekins P, Galaz V, Grace D, Graham H, Grubb M, Haines A, Hamilton I, Hunter A, Jiang X, Li M, Kelman I, Liang L, Lott M, Lowe R, Luo Y, Mace G, Maslin M, Nilsson M, Oreszczyn T, Pye S, Quinn T, Svensdotter M, Venevsky S, Warner K, Xu B, Yang J, Yin Y, Yu C, Zhang Q, Gong P, Montgomery H, Costello A (2015) Health and climate change: policy responses to protect public health. Lancet 386:1861-1914. https://doi.org/10.1016/S0140-6736(15)60854-6

Weber S, Sadoff N, Zell E, de Sherbinin A (2015) Policy-relevant indicators for mapping the vulnerability of urban populations to extreme heat events: a case study of Philadelphia. Appl Geogr 63:231-243. https://doi.org/10.1016/j.apgeog.2015.07.006

Wiréhn L, Danielsson Å, Neset TSS (2015) Assessment of composite index methods for agricultural vulnerability to climate change. J Environ Manag 156:70-80. https://doi.org/10.1016/j.jenvman. 2015.03.020

Wirehn L, Opach T, Neset TS (2017) Assessing agricultural vulnerability to climate change in the Nordic countries-an interactive geovisualization approach. J Environ Plan Manag 60:115-134. https://doi.org/10.1080/09640568.2016.1143351

Ye X, Wolff R, Yu W, Vaneckova P, Pan X, Tong S (2012) Ambient temperature and morbidity: a review of epidemiological evidence. Environ Health Perspect 120:19-28. https://doi.org/10.1289/ehp. 1003198

Yoon DK (2012) Assessment of social vulnerability to natural disasters: a comparative study. Nat Hazards 63:823-843. https://doi.org/10. 1007/s11069-012-0189-2

Yu XL, Guo XL, Wu ZC (2014) Land surface temperature retrieval from Landsat 8 TIRS - comparison between radiative transfer equationbased method, Split Window Algorithm and Single Channel Method. Remote Sens 6:9829-9852. https://doi.org/10.3390/rs6109829

Zhou B, Rybski D, Kropp JP (2017) The role of city size and urban form in the surface urban heat island. Scient Rep 7. https://doi.org/10. 1038/s41598-017-04242-2

Publisher's note Springer Nature remains neutral with regard to jurisdictional claims in published maps and institutional affiliations. 